\title{
195. Differentiation of Isoelectric Cell Species in Amphibian Morulae and Blastulae
}

\author{
By Osamu NAKamura and Masatoshi Aochi \\ Department of Biology, Osaka Kyôiku University, Osaka \\ (Comm. by Yô K. OKADA, M. J. A., Oct. 12, 1970)
}

According to Ave, Kawakami and Sameshima (1968), cells dissociated from the presumptive ectoderm of Triturus gastrulae can be separated electrophoretically into three zones and those from the dorsal lip into two zones. They suggested that these zones consisted of different cell species with specific developmental potencies as well as specific isoelectric points.

The presumptive region of the organizer, i.e. the prospective dorsal lip, has been found to acquire its capacity for induction and self-differentiation epigenetically at the stage of the morula (Nakamura and Matsuzawa 1967; Nakamura 1967, 1968; Nakamura and Takasaki 1970; Nakamura, Takasaki and Mizohata 1970; Nakamura, Takasaki, Yamane, Obayashi, Kôno, Okamoto and Okumoto 1970).

Thus, an interesting problem is the relation between these cell species and the particular properties of the organizer. If the organizer originally consists of two cell species endowed with mesodermic potencies as supposed by Ave et al. (1968), acquisition of the capacity for differentiation will only involve activation of these potencies. On the contrary, if acquisition of the capacity involves epigenetic differentiation of blastomeres, as proposed by Nakamura's group, difference between the cell species should first become distinguishable at the morula stage. Moreover, in early embryos the difference in electrophoretic behavior of different cell species may not necessarily reflect different developmental potencies. Thus, the causal relation between the electrophoretic properties and the differentiation of blastomeres is of great interest.

To study these problems, we tested the electrophoretic properties of blastomeres in amphibian morulae and blastulae. The main results have been reported briefly at the International Congress of Embryology in Paris in 1968 and in lectures at the Universities of Helsinki and Palermo by the senior author in the same year. The present paper is a full report of the study.

Materials and method. Embryos of the Japanese urodele, Triturus pyrrhogaster, and the African anuran, Xenopus laevis, were 
used. Most experiments were made on morulae, blastulae and gastrulae, with a few preliminary studies on neurulae and tail-bud embryos. The developmental stages described by Okada and Ichikawa (1947) for Triturus and by Nieuwkoop and Faber (1956) for Xenopus were adopted.

Blastomeres in each presumptive region of the ectoderm and mesoderm were dissociated by treatment for 15-60 minutes with calcium- and magnesium free Holtfreter's solution containing $0.038 \%$ EDTA (ethylenediamine tetraacetate), adjusted to $\mathrm{pH} 6.6$ with phosphate buffer (dissociating medium). Dissociation required progressively longer at more advanced developmental stages. The dissociated cells were washed 4-5 times with approximately isotonic sucrose solution, and then submitted to electrophoresis.

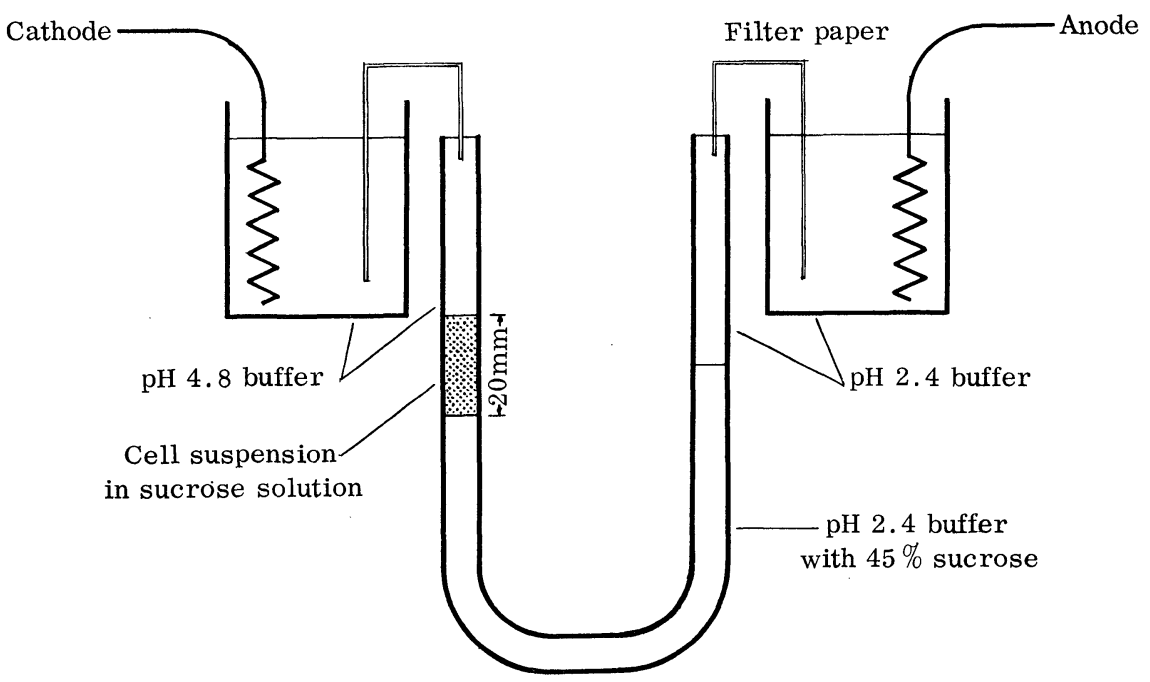

Fig. 1. Apparatus used for cell electrophoresis. As suspension medium in the cathodal leg sucrose solutions of appropriate concentration for each stage were used, as shown in Table I.

A U-tube similar to that described by Kolin (1955) was used for electrophoresis (Fig. 1). The method of Ave et al. (1968) was used with the modification that sucrose solutions were used instead of glycerine as the suspension medium for the cells, adjusting the specific gravity to that of the blastomeres at each stage. The concentrations of these solutions are given in Table I. Cells suspended in these solutions kept their original homogeneity for about 60 minutes at least.

These cells were subjected to electrophoresis at $0.2-0.5 \mathrm{~mA}$ and $175 \mathrm{~V}$ for 30 minutes in a refrigerator at $3.5^{\circ}-6.5^{\circ} \mathrm{C}$. 
Table I. Concentrations of sucrose solutions used for suspension of dissociated cells at each stage

\begin{tabular}{c|c|c|c|c|c}
\hline Stage & $6-6 \frac{1}{2}$ & 7 & 8 & $9-14$ & $23-26$ \\
\cline { 1 - 5 } $\begin{array}{c}\text { Concentration } \\
\text { of sucrose (\%) }\end{array}$ & 37.5 & 32.5 & 27.5 & 20 & 15 \\
\hline
\end{tabular}

Preliminary test 1. Electrophoresis of neural cells of Xenopus embryos.

a) Cells of the neural plate. The neural plate was cut out from Xenopus neurulae at st. 13-14 and treated with dissociating medium. Dissociated cells from the plates of 5 individuals were combined for electrophoresis.

On passing the electric current through the U-tube containing this cell suspension, almost all the cells moved upwards to form a single layer a little below the cathodal end of the medium. This layer corresponds to the $\mathrm{N}$ zone of Ave et al. (1968) and the $\mathrm{E}$ zone of Kawakami et al. (1967). We prefer the latter name, E (ectodermal) zone, because this layer was formed not only by neural cells but also by epidermal cells as reported by Kawakami et al. (1967). Only a few cells were observed in two other positions in the anodal half of the medium corresponding to the $\mathrm{M}_{1}$ and $\mathrm{M}_{2}$ zones of both the above papers.

b) Brain cells. The forebrain and midbrain were dissected out together from tail-bud embryos of Xenopus at st. 23-26. Specimens taken from 10 individuals were dissociated together. On electrophoresis this sample of brain cells formed a single layer of cells at a position corresponding to the $\mathrm{E}$ zone. In 4 of 5 samples, no layers were seen at the levels of the $M_{1}$ and $M_{2}$ zones (Fig. 2), while with the remaining sample, very faint layers of cells were detected at ths levels.

Preliminary test 2. Electrophoresis of somitic cells of Xenopus embryos.

Cells dissociated from somites of 5 Xenopus embryos at the tail-bud stage (st. 23-26) were examined by electrophoresis. They formed two zones, $M_{1}$ and $M_{2}$, but no E zone (Fig. 2 ).

Results of these preliminary tests are very similar to those obtained by previous authors with Triturus embryos. In anurans as in urodeles, neural tissues consist of cells of the $\mathrm{E}$ species while somites are composed of the $\mathrm{M}_{1}$ and $\mathrm{M}_{2}$ species.

Experiment 1. Electrophoresis of presumptive ectodermal cells in early Xenopus embryos.

Pieces $(0.4 \mathrm{~mm}$ diameter) of the presumptive ectoderm (areas of the neural plate and epidermis) of Xenopus laevis embryos were 
taken at st. $6-101 / 2$. Samples for electrophoresis were obtained from 5 or more embryos at st. 6-7 and from 3-5 embryos at st. 8-101/2. Results of electrophoretic analyses are summarized in Table II.

Table II. Numbers of samples from embryos of Xenopus leavis giving the respective electrophoretic patterns

\begin{tabular}{r|c|c|c|c|c|c|c|c}
\hline Region & Stage & 6 & $6 \frac{1}{2}$ & 7 & 8 & 9 & 10 & $10 \frac{1}{2}$ \\
\hline $\begin{array}{c}\text { Pattern } \\
\text { presumptive } \\
\text { ectoderm }\end{array}$ & $\mathrm{EM}_{1} \mathrm{M}_{2}$ & & 1 & 9 & 6 & 3 & 6 & 3 \\
\cline { 2 - 7 } & $\mathrm{EM}_{2}$ & 6 & 5 & 3 & & & & \\
\hline $\begin{array}{c}\text { Presumptive } \\
\text { mesoderm }\end{array}$ & $\mathrm{M}_{1} \mathrm{M}_{2}$ & & 1 & 9 & 6 & 3 & 7 & 4 \\
\cline { 2 - 7 } & $\mathrm{M}_{2}$ & 6 & 8 & 3 & & & & \\
\hline
\end{tabular}

From st. 8 to st. 101/2, namely in blastulae and early gastrulae, dissociated cells always formed three zones, $\mathrm{E}, \mathrm{M}_{1}$, and $\mathrm{M}_{2}$ (Fig.2). But, at st. 7 (early blastulae), two types of electrophoretic patterns were seen, one consisting of three zones $\left(\mathrm{E}, \mathrm{M}_{1}\right.$, and $\left.\mathrm{M}_{2}\right)$ and the other of two zones ( $\mathrm{E}$ and $\mathrm{M}_{2}$ ). The former type predominated, the frequency of occurrence of the latter being only $25 \%$. Further, at st. $6 \frac{1}{2}$, only one of 6 samples formed three zones, the others forming two zones $\mathrm{E}$ and $\mathrm{M}_{2}$.

In morulae at st. 6, blastomeres are few in number and so voluminous that some of them contains presumptive materials for both ectoderm and mesoderm. Accordingly, 10 or more embryos were needed to obtain a sample for electrophoresis of purely ectodermic blastomeres, without those of dual nature. On electrophoresis these samples invariably formed two zones $\mathrm{E}$ and $\mathrm{M}_{2}$ (Fig. 2).

\begin{tabular}{c|cccc}
\hline Stage & Morula & Blastula & Gastrula & Tail-bud \\
\hline Region & & & & \\
\hline $\begin{array}{c}\text { Mesoderm } \\
\text { (dorsal) }\end{array}$ & & & & \\
\hline
\end{tabular}

Fig. 2. Representative electrophoretic patterns of cells. 'Ectoderm' in the tail-bud stage shows the pattern of brain cells; 'mesoderm' in the same stage gives the pattern of somitic cells. 
A mixture of ectodermic and mesodermic blastomeres was also submitted to electrophoresis. This mixture, too, formed two zones $\mathrm{E}$ and $\mathrm{M}_{2}$, with no $\mathrm{M}_{1}$ layer.

Experiment 2. Electrophoresis of cells of the presumptive organizer in early Xenopus embryos.

The dorsal marginal zone, i.e. the prospective organizer, was cut out from Xenopus laevis embryos at st. 6-101/2. Special care was taken not to include cells of the adjacent neural region. Pieces from 3-5 embryos at each stage were dissociated and combined for electrophoresis. As shown in Table II, cells at st. 8-101/2 formed two zones, $\mathrm{M}_{1}$ and $\mathrm{M}_{2}$. At st. 7 some samples formed only zone $\mathrm{M}_{2}$, though usually two zones were formed. At st. 61/2 eight samples gave only a single zone, while one formed two zones. At st. 6 all samples gave only zone $\mathrm{M}_{2}$.

Experiment 3. Electrophoresis of presumptive ectodermal and mesodermal cells in early Triturus embryos.

Similar experiments were made on Triturus pyrrhogaster embryos at st. 7-11 and results are shown in Table III.

At st. 8-11, presumptive ectodermal cells formed three zones, $\mathrm{E}, \mathrm{M}_{1}$, and $\mathrm{M}_{2}$, while presumptive mesodermal cells in the dorsal marginal zone formed two zones, $\mathrm{M}_{1}$ and $\mathrm{M}_{2}$.

Embryos at st. 7 were distinguished into two stages, $7 \mathrm{a}$ and $7 \mathrm{~b}$. The number of cells counted across the diameter of the animal hemisphere in st. $7 \mathrm{a}$ was $10-13$ and in st. $7 \mathrm{~b}$ was $14-16$. At st. $7 \mathrm{~b}$, neither ectodermic nor mesodermic blastomeres showed uniform electrophoretic patterns. The ectodermic blastomeres formed either three zones $\left(\mathrm{E}, \mathrm{M}_{1}\right.$, and $\mathrm{M}_{2}$ ) or two zones ( $\mathrm{E}$ and $\mathrm{M}_{2}$ ), while mesodermic blastomeres formed two zones $\left(M_{1}\right.$ and $\left.M_{2}\right)$ or only one $\left(M_{2}\right)$. At st. 7a, ectodermic blastomeres formed two zones ( $\mathrm{E}$ and $\mathrm{M}_{2}$ ) only and mesodermic ones invariably formed one zone $\left(\mathrm{M}_{2}\right)$.

Table III. Numbers of samples from embryos of Triturus pyrrhogaster giving the respective electrophoretic pattern

\begin{tabular}{c|c|c|c|c|c|c|c}
\hline \multirow{2}{*}{ Region } & Stage & \multicolumn{2}{|c|}{7} & 8 & 9 & 10 & 11 \\
\cline { 2 - 7 } & Pattern & $\mathrm{a}$ & $\mathrm{b}$ & & & & \\
\hline $\begin{array}{c}\text { Presumptive } \\
\text { ectoderm }\end{array}$ & $\mathrm{EM}_{1} \mathrm{M}_{2}$ & & 1 & 5 & 6 & 3 & 3 \\
\hline & $\mathrm{EM}_{2}$ & 3 & 2 & & & & \\
\hline $\begin{array}{c}\text { Presumptive } \\
\text { mesoderm }\end{array}$ & $\mathrm{M}_{1} \mathrm{M}_{2}$ & & 1 & 5 & 5 & 3 & 4 \\
\cline { 2 - 7 } & $\mathrm{M}_{2}$ & 3 & 5 & & & & \\
\hline
\end{tabular}

Discussion. Results of preliminary tests with Xenopus laevis embryos are quite similar to those with Triturus pyrrhogaster 
embryos obtained by Ave et al. (1968). This suggests not only that the cell species of embryonal tissues in anurans and urodeles are similar, but also that the methods adpoted in the present study and by previous authors are equally reliable.

In both Xenopus and Triturus embryos at and after st. 8, cells dissociated from the presumptive ectoderm formed three zones, E, $\mathrm{M}_{1}$, and $\mathrm{M}_{2}$, on electrophoresis, while those from the presumptive mesoderm in the region of the organizer formed two zones, $M_{1}$ and $\mathrm{M}_{2}$. This is in good accordance with results obtained by the above authors with early gastrulae of Triturus. But, at or before st. 7, different electrophoretic patterns were obtained.

In Xenopus embryos at st. 6 and Triturus embryos at st. 7a, no middle layer $\mathrm{M}_{1}$ was formed. Accordingly, ectodermic blastomeres formed zones $\mathrm{E}$ and $\mathrm{M}_{2}$ while mesodermic blastomeres formed only zone $\mathrm{M}_{2}$. At the next stage, i.e. st. $6 \frac{1}{2}$ in Xenopus and at st. $7 \mathrm{~b}$ in Triturus, zone $\mathrm{M}_{1}$ appeared in some samples. On electrophoresis of cells from Xenopus embryos at st. 7 , samples usually formed zone $\mathbf{M}_{1}$. And at st. 8, all samples of ectodermic and mesodermic blastomeres from both Xenopus embryos and Triturus embryos formed zone $\mathrm{M}_{1}$.

Thus, the $M_{1}$ species of blastomere cells is differentiated epigenetically at a late stage of the morula. It is interesting that this stage approximately corresponds to that for acquisition of the capacities of self-differentiation and induction of the organizer. However, at this stage cells of the $M_{1}$ species are found not only in the dorsal marginal zone but also in the presumptive ectoderm. On the other hand, mesodermic blastomeres differ from ectodermic ones in containing no cells of the $\mathrm{E}$ species even in thirty-two cell stage (st. 6) when the $\mathrm{M}_{1}$ species of cells is not yet differentiated. This difference is probably related to the acquisition of the particular properties of the organizer together with the appearance of the $\mathrm{M}_{1}$ species of cells but there is no direct evidence for this.

Determination involves both positive and negative processes, as emphasized by Vogt (1927) ; the former being "limitation of potencies" and the latter "evocation of faculties". The selective killing effect of inducing substance on different cell species reported by Ave et al. (1968) may have to do with the negative process. But, we consider that some positive effects are more important for acquisition of new capacities and for completion of induction. At present it is uncertain whether the appearance of a new cell species $\left(M_{1}\right)$ indicates "evocation of faculties". Further studies are required to elucidate these causal relations between the epigenetic differentiation of isoelectric cell species and acquisition of particular developmental properties of parts of the embryo. 